\title{
Effect of Pre-Freezing Aging Temperatures on Quality Attributes of Beef Rumps
}

\author{
Muhammad Bilal Akram ${ }^{1 *}$, Fozia Munir ${ }^{2}$, Muhammad Issa Khan ${ }^{3}$, Muhammad Shoaib $^{4}$, Shahiryar Khalid ${ }^{5}$
}

${ }^{1}$ Student, National Institute of food science and Technology, Faculty of Food Nutrition and Home Science, University of Agriculture, Faisalabad, Pakistan

${ }^{2}$ Student, National Institute of food science and Technology, Faculty of Food Nutrition and Home Science, University of Agriculture, Faisalabad, Pakistan

${ }^{3}$ Associate Professor, National Institute of food science and Technology, Faculty of Food Nutrition and Home Science, University of Agriculture, Faisalabad, Pakistan

${ }^{4}$ Student, Institute of Microbiology, University of Agriculture, Faisalabad, Pakistan

${ }^{5}$ Student, National Institute of food science and Technology, Faculty of Food Nutrition and Home Science, University of Agriculture, Faisalabad, Pakistan

*Address for Correspondence Mr. Muhammad Bilal Akram, Student, National Institute of Food Science and Technology, Faculty of Food Nutrition and Home Science, University of Agriculture, Faisalabad, Pakistan

E-mail: mbilalakram3766@gmail.com

\section{Received: 16 Jul 2018/ Revised: 09 Nov 2018/ Accepted: 26 Feb 2019}

\begin{abstract}
Background: Meat is animal flesh mainly consumed for its valuable sources of essential amino acids, fatty acids, and micronutrients. Aging of meat improves its quality characteristics by accelerating protease ( $\mu$ calpain, cathepsins) and lipase enzymes activity. Freezing of meat is done to maintain quality characteristics for a longer period of time. The objective of this study was to estimate the effect of different pre-freezing aging temperatures on the quality attributes of beef rumps.

Methods: The beef rumps were individually assigned to different aging temperature treatments before freezing: $\mathrm{T}_{1}$ at $2^{\circ} \mathrm{C}$ for 3 days, $T_{2}$ at $2^{\circ} \mathrm{C}$ for 7 days, $\mathrm{T}_{3}$ at $4^{\circ} \mathrm{C}$ for 3 days and $\mathrm{T}_{4}$ at $4^{\circ} \mathrm{C}$ for 7 days.

Results: The beef rumps aged at relatively low temperature as at $2^{\circ} \mathrm{C}$ for 3 days and 7 days showed improved results for texture profile; shear force, tenderness, color and protein fractionation as compared to the aged rumps at $4^{\circ} \mathrm{C}$ for 3 days and 7 days. Lipids oxidation was more at $4^{\circ} \mathrm{C}$ for 7 days aging while color stability of beef rumps was observed at $2^{\circ} \mathrm{C}$ for 3 days as compared to $4^{\circ} \mathrm{C}$ for 3 days. Cooking loss, drip loss and $\mathrm{pH}$ were less affected by differences in aging conditions and showed similar results.

Conclusion: These results demonstrated that aging of beef rumps at $2^{\circ} \mathrm{C}$ for 3 days before freezing improved tenderness, color and protein fractionation without adversely affecting the texture profile.
\end{abstract}

Key-words: Aging, Aging temperatures, Cooking loss, Color stability, Freezing, Shear force

\section{INTRODUCTION}

Meat is animal flesh consumed as food and considered as a valuable ingredient in meals ${ }^{[1]}$. Meat is composed of various health beneficial nutrients such as proteins, vitamins i.e. $B_{12}, B_{6}, D$ and micronutrients like iron, zinc and phosphorus. Chemically meat is composed of moisture, proteins, fats and minerals ${ }^{[2]}$.

\section{How to cite this article}

Akram MB, Munir F, Khan MI, Shoaib M, Khalid S. Effect of PreFreezing Aging Temperatures on Quality Attributes of Beef Rumps. SSR Inst. Int. J. Life Sci., 2019; 5(2): 2205-2210.

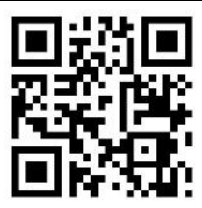

Meat is contemplated as an important part of food in the human diet, mainly in the developed countries. In Pakistan production of beef has been 2085 metric tons during 2016-17 ${ }^{[3]}$. Aging of meat basically recognized as "ripening" as well as "conditioning" and considered a natural phenomenon and a convenient method to improve the quality and palatability of meat ${ }^{[4]}$. The aging of beef is normally thought of like the time, in days, from slaughtering to until the carcass is broken down into retail cuts ${ }^{[5]}$. The aging time for beef in the industry is the time after slaughtering to the division of carcass into further cuts, which were seven days top ${ }^{[6]}$. Meat being perishable commodity required handling to prevent deterioration and after slaughtering various changes 
occur in meat during aging including protein denaturation, lipid oxidation due to various enzymatic actions ${ }^{[7]}$. Post-mortem carcass processing during the first 24 hours considerably affects the eventual meat quality characteristics such as tenderness, water holding capacity and color. The effects of aging on tenderness are more evident in older animals as compare to younger animal's carcasses. Mainly temperature is considered highly influential on the rate of enzymatic processes which led to changes in the tenderness and flavor of meat ${ }^{[8]}$. Freezing is a widely used technique and one of the most prominent methods used for the preservation of meat products for prolonging storages. Because of its importance in prolonging the shelf life of frozen and thawed meat, freezing is contemplated as most important for quality preservation of frozen products as compare to those of which are never frozen ${ }^{[9]}$. Freezing often results in cell damaging of muscles structures due to the formation of ice crystals and water losses due to thawing after freezing which ultimately affects other quality attributes like water retention, lipid oxidation and palatability. Freezing is one of the most practiced, effective and efficient methods for food preservation ${ }^{[10]}$. Although the significant effects of aging at relatively high temperature on tenderness of meat has been studied but some other quality attributes as drip loss, cooking loss and color stability has not been studied much in relation to aging at higher temperatures before freezing. Therefore, the main objective of this study is to evaluate the effects of aging at different temperatures on the quality attributes of the beef rumps.

\section{MATERIALS AND METHODS}

Procurement of raw materials and processing- Beef raw meat was procured from local market and transported to the Meat Science and Technology Laboratory at National Institute of Food Science and Technology in University of Agriculture, Faisalabad, Pakistan March to November 2018 for analytical study, after 24 hours of slaughtering beef rumps were prepared and vacuum packaged followed by the placement of the rumps at different temperatures as treatment $T_{0}$ being control treatment (un-aged) while $\mathrm{T}_{1}$ at $2^{\circ} \mathrm{C}$ for 3 days, $\mathrm{T}_{2}$ at $2^{\circ} \mathrm{C}$ for 7 days, $T_{3}$ at $4^{\circ} \mathrm{C}$ for 3 days and $T_{4}$ at $4^{\circ} \mathrm{C}$ for 7 days in the refrigerator. The temperature was continuously checked and maintained using a standardized thermometer. At the end of aging period, beef rumps were analyzed for drip loss, cooking loss, yield, shear force, color stability and lipid oxidation (TBARS). Then freezing of aged beef rumps was done at $-18^{\circ} \mathrm{C}$ for 30 days and sensory analysis was done.

$\mathrm{pH}$ - The $\mathrm{pH}$ was measured by taking $10 \mathrm{~g}$ test sample of each treatment and making volume up to $100 \mathrm{ml}$ after adding distilled water then this mixture was homogenized for 60 seconds and slurry was formed. The $\mathrm{pH}$ meter was calibrated with buffers of $\mathrm{pH} \mathrm{4,} \mathrm{7,} 10$ for accurate results then the probe of $\mathrm{pH}$ meter was dipped in prepared slurry and $\mathrm{pH}$ was measured by taking notes on screen of digital $\mathrm{pH}$ meter. The readings were taken in triplicates as described in AOAC ${ }^{[11]}$.

Drip loss, cooking loss and yield- Drip loss was determined by taking cubes of muscles $(1.5 \mathrm{~cm}$ thickness and about $39 \mathrm{~g}$ ) after removal of all visible fats and tissues. The sample cubes were placed in the plastic bag in suspended form (by removing air) and placed at a specific temperature of $4^{\circ} \mathrm{C}$ for 24 hours as described by Filho et al. ${ }^{[12]}$. After 24 hours of beef rumps sample cubes were dried and weighed. The drip loss was calculated by taking weights before and after refrigeration and expressing in terms of percentage. Cooking loss of the beef rumps was measured by calculating weight differences of beef rumps cube cuts of specified thickness ( $1 \mathrm{~cm}$ and $28 \mathrm{~g}$ ) placed in a plastic bag before and after cooking by immersing in the hot water bath at $80^{\circ} \mathrm{C}$ for 1 hour. After cooking cubes were blotted dry and cooled at room temperature followed by weighing as given in AOAC ${ }^{[11]}$. The yield of beef rumps was determined by dividing weights of cubic cuts before and after cooking. Yield is actually the amount of products remaining after cooking. Trim losses are deducting from yield AOAC ${ }^{[11]}$.

Color Stability and shear force- Ground meat samples of beef rumps were taken and stored for 20 minutes at refrigeration temperature of $4^{\circ} \mathrm{C}$ for color determination. Samples were kept in refrigerator to make myoglobin active on surface layer. Hunter lab scan XE apparatus was used for color determination. The values were observed for redness, lightness and yellowness for each test sample as described by AMSA ${ }^{[13]}$. Shear force was measured by obtaining six muscles cuts of each treatment of beef rumps of specific thickness $(1 \mathrm{~cm} \times 1$ $\mathrm{cm}$ ). The needle of the instrument (texture analyzer) was allowed to pass through the cuts and force was measured as required by the needle to pierce through 
the beef muscles. Shear force is the estimation of tenderness before and after aging at varying temperatures as described by McGlone et al. ${ }^{[14]}$.

TBARS assay- Thiobarbituric acid reactive substances assay was done to determine the extent of lipid peroxidation in meat samples followed by measuring spectroscopic absorptions using the method modified by Reitznerova et al. ${ }^{[15]}$. Minced beef rumps sample (5 g) for each replicate was taken and $15 \mathrm{ml}$ distilled water

\section{RESULTS}

Proximate analysis of beef ramp meat was determined as shown in Table 1 . For quality analysis $\mathrm{pH}$, drip loss, cooking loss and yield percentage of different meat was added in it. After homogenization (5 minutes at $4000 \mathrm{rpm}$ at $4^{\circ} \mathrm{C}$ ) $1 \mathrm{ml}$ of the supernatant of the samples was obtained and added in test tubes. Butylated hydroxy toluene (50 $\mu \mathrm{l}$ of $7.2 \%$ ) and Thiobarbituric acid along with $2 \mathrm{ml}$ trischloroacetic acid (TCA) solution were mixed with supernatant. The absorbance was taken in spectrophotometer at $532 \mathrm{~nm}$ after cooking in hot water bath $\left(90^{\circ} \mathrm{C}\right.$ for 30 minutes) followed by centrifugation and cooling.

treated was evaluated as shown in Table 2. Color stability of beef ramp meat as well as shear force and TBARS of beef meat was determined to check the meat quality as shown in Table 3.

Table 1: Mean Values of Proximate analysis for beef meat

$\begin{array}{lllll}\text { Sample } & \text { Moisture (\%) } & \text { Protein (\%) } & \text { Fat (\%) } & \text { Ash (\%) }\end{array}$

Raw Beef

$72.4 \pm 0.85$

$22.53 \pm 1.03$

$4.15 \pm 0.37$

$0.47 \pm 0.05$

Table 2: Mean Values of $\mathrm{pH}$, drip loss, cooking loss and yield of ramp beef meat

\begin{tabular}{ccccc}
\hline Treatments & $\mathrm{pH}$ & Drip loss (\%) & Cooking loss (\%) & Yield (\%) \\
\hline$T_{0}$ & $5.76 \pm 0.02$ & $2.86 \pm 0.12$ & $29.66 \pm 0.30$ & $85.20 \pm 0.99$ \\
$T_{1}$ & $5.62 \pm 0.009$ & $5.97 \pm 0.02$ & $28.13 \pm 0.81$ & $84.00 \pm 0.81$ \\
$T_{2}$ & $5.65 \pm 0.01$ & $6.40 \pm 0.01$ & $29.00 \pm 0.62$ & $82.10 \pm 0.62$ \\
$T_{3}$ & $5.63 \pm 0.009$ & $6.70 \pm 0.01$ & $29.66 \pm 0.36$ & $83.13 \pm 0.20$ \\
$T_{4}$ & $5.65 \pm 0.01$ & $6.93 \pm 0.15$ & $27.33 \pm 0.90$ & $81.90 \pm 0.98$ \\
\hline
\end{tabular}

$T_{0}=$ un-aged, $T_{1}=2^{\circ} \mathrm{C}$ for 3 days, $T_{2}=2^{\circ} \mathrm{C}$ for 7 days, $T_{3}=4^{\circ} \mathrm{C}$ for 3 days, $T_{4}=4^{\circ} \mathrm{C}$ for 7 days

Table 3: Mean Values of TBARS, Shear force, color of ramp beef meat

\begin{tabular}{cccccc}
\hline Treatments & $\begin{array}{c}\text { TBARS } \\
(\mathbf{m g} / \mathbf{k g})\end{array}$ & Shear force $(\mathbf{N})$ & $\begin{array}{c}\mathbf{L}^{*} \\
\text { (lightness) }\end{array}$ & $\begin{array}{c}\mathbf{a}^{*} \\
\text { (redness) }\end{array}$ & $\begin{array}{c}\mathbf{b}^{*} \\
\text { (yellowness) }\end{array}$ \\
\hline $\mathbf{T}_{\mathbf{0}}$ & $1.03 \pm 0.015$ & $41.33 \pm 0.35$ & $40 \pm 1.0$ & $12.7 \pm 0.2$ & $8.86 \pm 0.35$ \\
$\mathbf{T}_{\mathbf{1}}$ & $1.78 \pm 0.01$ & $43.13 \pm 0.25$ & $42.4 \pm 0.43$ & $19.2 \pm 0.09$ & $8.16 \pm 0.11$ \\
$\mathbf{T}_{2}$ & $1.80 \pm 0.01$ & $40.9 \pm 0.49$ & $42.9 \pm 0.15$ & $9.6 \pm 0.15$ & $8.36 \pm 0.15$ \\
\hline
\end{tabular}




$\begin{array}{lrrrrr}\mathbf{T}_{3} & 1.79 \pm 0.15 & 41.56 \pm 1.10 & 43.2 \pm 0.085 & 17.3 \pm 0.41 & 7.80 \pm 0.10 \\ \mathbf{T}_{4} & 1.83 \pm 0.01 & 39.66 \pm 0.96 & 43.2 \pm 0.60 & 8.8 \pm 0.35 & 8.73 \pm 0.21\end{array}$

$T_{0}=$ un-aged, $T_{1}=2^{\circ} \mathrm{C}$ for 3 days, $T_{2}=2^{\circ} \mathrm{C}$ for 7 days, $T_{3}=4^{\circ} \mathrm{C}$ for 3 days, $T_{4}=4^{\circ} \mathrm{C}$ for 7 days

$\mathrm{a}^{*}=$ Values which is redness of the beef rumps mainly basic color responsible for acceptance is showed by higher values in case of $2^{\circ} \mathrm{C}$ for 3 days aging temperature and period.

$b^{*}=$ Values showed yellowness of the beef rumps and its values are maximum in case of $4^{\circ} \mathrm{C}$ for 7 days among treatments but less than fresh and un-aged beef rumps.

\section{DISCUSSION}

The $\mathrm{pH}$ is a critical factor for meat quality maintenance and after 24 hours of postmortem $\mathrm{pH}$ of the beef rumps was recorded as 5.76 shown in Table 2. Significant changes were observed in the values of $\mathrm{pH}$ of the beef rumps after 24 hours of slaughtering and aged at different temperatures. The $\mathrm{pH}$ values were changed from 5.76 to 5.62 showing decreasing trend in the values. $T_{1}$ treatment showed the minimum value of 5.62 as compared to the treatment $T_{2}$ and $T_{4}$ which showed 5.65. Treatment $T_{3}$ showed value in between $T_{1}$ and $T_{4}$. The finding was found to be in similar trend as described by Hou et al. ${ }^{[16]}$ and it was related to the post mortem anaerobic respiration which led towards the lactic acid formation, therefore due to this reason $\mathrm{pH}$ inclined towards acidic in nature. Drip loss of the beef rumps aged at $2^{\circ} \mathrm{C}$ and $4{ }^{\circ} \mathrm{C}$ varied from 5.97 to $6.93 \%$ are remarkably different from un-aged beef rumps as in $2.86 \%$ (Table 2). The results observed in accordance with the findings of Stevik et al. ${ }^{[17]}$ for the drip loss of meat samples. It was observed that the differences in storage conditions influenced the drip loss positively with the temperature of $1-4^{\circ} \mathrm{C}$ but further increase in temperature did not significantly affect the drip loss. Cooking loss of the aged beef rumps at $2^{\circ} \mathrm{C}$ for 7 days is observed more $29 \%$ along with $4^{\circ} \mathrm{C}$ aging for 3 days $29.66 \%$ as compared to the beef rumps aged at $2^{\circ} \mathrm{C}$ for 3 days and $4^{\circ} \mathrm{C}$ for 7 days (Table 2). But the differences in the cooking losses of different treatments are not significant much and are in similar range. $\mathrm{Oz}{ }^{[18]}$ studied the cooking losses of the meat samples cooked by using different methods and established that cooking losses during storage periods under varied conditions of temperature showed significantly diverse results. Similarly increase in temperature increased the proteolytic enzymes activity marginally which results in more proteolysis of meat proteins and hence this phenomenon can be used to explain the variations in cooking losses.
Yield results of aged beef rumps showed that with the passage of time during storage period decline in the values of the yield is observed. Aging at $2^{\circ} \mathrm{C}$ for 3 days showed the maximum value of the yield as $84.00 \%$ (Table 2). Haytowitz et al. ${ }^{[19]}$ conducted a study on the composition of meat in different conditions of storage and stated the facts that yield of the meat exist in this particular range. This decline in the yield of the aged beef rumps is attributed to the increase in water losses (cooking and drip loss) which ultimately cause lower yielding trends with the increase of the aging period. Thiobarbituric acid reactive substances measurement is done to estimate lipid oxidation of meat cuts. It ultimately affects the shelf life of meat products. TBARS assay of the aged beef rumps have shown that beef rumps aged at $4^{\circ} \mathrm{C}$ for 7 days as $1.83 \mathrm{mg} / \mathrm{kg}$ (Table 3 ). TBARS assay showed the extent of lipid oxidation food as lipid oxidation process is a chain reaction continuously occurred once started. In TBARS assay actually expresses in malondialdehyde milligram per kilogram of meat. In a study done by Filgueras et al. ${ }^{[20]}$ to estimate the lipid oxidation of meat samples during vacuum storage showed that the lipid oxidation of the muscles enhanced with the increase in storage period. This is mainly due to lipolytic enzymes activity along with other mechanisms involved in the lipids breakdown. Shear force is the indicator of the tenderness of beef and it is usually chewiness of the food products to estimate the amount of force required to break down a product. The results showed that $4^{\circ} \mathrm{C}$ temperature treatments for 7 days were tenderer among of all other treatments. $2^{\circ} \mathrm{C}$ for 7 days also showed more tenderness and less shear force as $40.9 \mathrm{~N}$ (Table 3). Ishihara et al. ${ }^{[21]}$ studied shear force to measure tenderness of treated beef samples during storage under dry conditions and suggested that shear force for fresh samples of meat was more as compared to treated meat samples. Shear force analysis of the aged beef rumps at different temperatures showed that with the progression of the aging period for both 
temperatures shear force declines because of the muscles breakdown due to various enzymatic activities. Color or appearance is the first thing noticed by consumers therefore; color is an important quality attribute of any food product and plays a major role in the consumer acceptance of foods. The color analysis of the aged beef rump at $2^{\circ} \mathrm{C}$ and $4{ }^{\circ} \mathrm{C}$ for 3 and 7 days demonstrated that the $\mathrm{L}^{*}$ values of color which showed lightness is higher in case of elevated temperature as $4^{\circ} \mathrm{C}$ for both aging periods as 43.2 (Table 3). Chakanya et al. ${ }^{\text {[22] }}$ cleared that the color properties of the beef stored at low temperature showed similar trends with the slight difference in the values range due to the differences in the types of the cuts and conditions. Red meat's typical red color is due to the presence of meat proteins myoglobin and its determination showed the freshness of the samples. The changes occurred in the different color parameters of the beef cuts are due to the responsible protein oxidation as in case of meat is myoglobin. Higher temperatures favor the enzymatic activity responsible for the formation of oxymyoglobin, which results in a darker appearance of the beef rumps.

\section{CONCLUSIONS}

With the passage of time the preservation and maintenance of quality along with palatability of food products in accordance with consumer demands needed to be improved. Aging of meat was an effective method for the improvement of quality attributes with side by side development of the desirable palatability traits. Aging of beef rumps at a relatively low temperature as $2^{\circ} \mathrm{C}$ for 3 days and 7 days as compared to $4{ }^{\circ} \mathrm{C}$ for 3 and 7 days respectively resulted in similar improvements in the quality characteristics. With the increase in aging period shear force showed a decreasing trend for both temperatures of $2^{\circ} \mathrm{C}$ and $4^{\circ} \mathrm{C}$ mainly for 7 days resulting in the enhanced tenderness of the beef rumps. Color stability was observed more at $2^{\circ} \mathrm{C}$ for 3 days aging along with similar stage at $4^{\circ} \mathrm{C}$ for 3 days aging. TBARS values showed that as aging progressed lipid oxidation accelerated in the beef rumps as compared to un-aged beef rumps. Cooking loss, drip loss and yield of the beef rumps were observed more at $2^{\circ} \mathrm{C}$ aging for mainly 3 days as compared to 7 days.

Conclusively it is suggested that aging at relatively lower temperature can be beneficial as with the increase in temperature food items are more prone to spoilage.
Protein fractionation with the increase in temperature before freezing needs to be further studied.

\section{ACKNOWLEDGMENTS}

The authors are grateful to Associate Professor Dr. Muhammad Issa Khan for valuable comments to the manuscript.

\section{CONTRIBUTION OF AUTHORS}

Research concept- Muhammad Issa Khan, Muhammad Bilal Akram

Research design- Muhammad Issa Khan, Muhammad Bilal Akram

Supervision- Muhammad Issa Khan

Materials- Muhammad Issa Khan

Data collection- Shahiryar Khlid, Muhammad Bilal Akram

Data analysis- Muhammad Bilal Akram, FoziaMunir, Muhammad Shoaib

Literature search- Shahiryar Khlid, Muhammad Bilal Akram, Muhammad Shoaib

Writing article- Muhammad Bilal Akram

Critical review- Muhammad Issa Khan

Article editing- Muhammad Bilal Akram

Final approval- Muhammad Issa Khan

\section{REFERENCES}

[1] Lawrie RA, Ledward DA. Lawrie's Meat Science. $7^{\text {th }}$ ed. CRC Press, 2006.

[2] Cabrera MC, Saadoun A. An overview of the nutritional value of beef and lamb meat from South America. Meat Sci., 2014; 98(3): 435-44.

[3] Government of Pakistan. Pakistan Economic Survey, 2016.

[4] Lamare M, Taylor GR, Farout L, Briand Y, Briand M. Changes in proteasome activity during postmortem aging of bovine muscle. Meat Sci., 2002; 61(2): 199-204.

[5] Ahnstrom ML, Seyfert M, Hunt MC, Johnson DC. Dry aging of beef in a bag highly permeable to water vapour. Meat Sci., 2006; 73(4): 674-79.

[6] Hanzelkova S, Simeonovova J, Hampel D, Dufek A, Subrt J. The effect of breed, sex and aging time on tenderness of beef meat. Meat Sci., 2011; 80(2): 191-96.

[7] Kim YHB, Luc G, Rosenvold K. Pre rigor processing, ageing and freezing on tenderness and color stability of lamb loins. Meat Sci., 2013; 95(2): 412-18. 
[8] Kemp CM, Sensky PL, Bardsley RG, Buttery PJ, Parr T. Tenderness-an enzymatic view. Meat Sci., 2010; 84(2): 248-56.

[9] Mortensen M, Andersen HA, Engelsen SB, Bertram HB. Effect of freezing temperature, thawing and cooking rate on water distribution in two pork qualities. Meat Sci., 2006; 72(1): 34-42.

[10]Ngapo TM, Babare IH, Reynolds J, Mawson RF. Freezing and thawing rate effects on drip loss from samples of pork. Meat Sci., 1990; 53(3): 149-58.

[11]AOAC. Official method of analysis of the association of official analytical chemists. $17^{\text {th }}$ edition. Association of Official Analytical Chemists. Washington, DC, USA, 2006.

[12]Filho RDTA, Cazedey HP, Fontes PR, Ramos ADLS, Ramos EM. Drip loss assessment by different analytical methods and their relationships with pork quality classification. J. Food. Quali., 2017; 17(1): 1-8.

[13]AMSA. Guidelines for the measurement of meat color. $2^{\text {nd }}$ edition. American Meat Science Association. Washington, DC, USA, 2012.

[14]McGlone, VA, Devine CE, Wells RE. Detection of tenderness, post-rigor age and water status changes in sheep meat using near Infrared Spectroscopy. Hort. Res., 2005; 13(3): 277-85.

[15]Reitznerova A, Sulekova M, Nagy J, Cak SM, Semjon $B$, et al. Lipid peroxidation process in meat and meat products: A comparison study of malondialdehyde determination between modified 2-thiobarbituric acid spectrophotometric method and reverse-phase high-performance liquid chromatography. Mol., 2017; 22(11): 01-12.
[16] Hou X, Liang R, Mao Y, Zhang Y, Niu L, et al. Effect of suspension method and aging time on meat quality of Chinese fattened cattle $M$. Longissimus dorsi. Meat Sci., 2014; 96(1): 640-45.

[17]Stevik A, Duun AS, Rustad T, O'Farrell M, Schulerud $H$, et al. Ice fraction assessment by near-infrared spectroscopy enhancing automated super shilling process lines. J. Food. Engi., 2010; 100(1): 169-77.

[18]Oz F, Celik T. Proximate composition, color and nutritional profile of raw and cooked goose meat with different methods. J. Food Process. Preserv., 2015; 39(6): 2442-54.

[19]Haytowitz DB, Pehrsson PR, Holden JM. The identification of key foods for food composition research. J. Food Compost. Anal., 2015; 15(2): 183-94.

[20]Filgueras RS, Aubry GP, Thomas L, Bauchart A, Durand $D$, et al. Colour, lipid and protein stability of Rhea americana meat during air-and vacuumpackaged storage: Influence of muscle on oxidative processes. Meat Sci., 2010; 86(3): 665-73.

[21] Ishihara Y, Moreira R, Souza GD, Salviano A, Madruga $M$. Study of the Warner shear force, sensory analysis and sarcomere length as indicators of the tenderness of sun-dried beef. Molecules, 2013; 18(8): 9432-40.

[22]Chakanya C, Arnaud E, Muchenje V, Hoffman LC. Colour and oxidative stability of mince produced from fresh and frozen/thawed fallow deer (Damadama) meat. Meat Sci., 2017; 26(3): 63-72. 